\title{
Diabetes Related Distress among Assiut University Students with Type (1) Diabetes Mellitus Attending Students' Clinic
}

Tarneem M. Khodairy, ${ }^{1}$ Saeed S. Abduljalil, ${ }^{2 *}$ Mohammad H. Qayed, ${ }^{3}$ Yasser M. Badr Aldin $\mathrm{Al}$ sorogy ${ }^{3}$

\begin{abstract}
:
Background: Diabetes is one of the largest global health emergencies of the 21st century, In Egypt, there were over 7.8 million cases of diabetes in 2015 of diabetic complications, Diabetes-related distress (DD) is very common in people with diabetes and their family members.
\end{abstract}

Objectives: To investigate the diabetes related distress among students with type (1) Diabetes Mellitus its different sources and its associated factors like glycemic control.

Methods: Study participants demographic data was collected from electronic patient records, Diabetes related distress and its different sources was detected using T1DDS tool developed especially for those with type 1 diabetes mellitus and HbAlc was measured for every participant.

Results: $73.7 \%$ of Students with Type1 Diabetes Mellitus reported at least moderate diabetes related distress, Powerlessness and Eating Distress have the highest mean levels, followed by Hypoglycemia Distress and Management Distress in the mid-range mean levels, and diabetes related distress was significantly linked to the level of glycemic control. Conclusion: The prevalence of DD was high among the study participants, higher DD was reported for poor glycemic control arguing for a need to address DD in clinical care.

Key words: Diabetes, type 1, distress, university students

\section{Introduction:}

Diabetes-related distress (DD) is distinct from depressive disorders and is very common in people with diabetes and their family members. ${ }^{(1)}$ Diabetes-related distress refers to significant negative psychological reactions related to emotional burdens and worries specific to an individual's experience in having to manage a severe, complicated, and demanding chronic disease such as diabetes. ${ }^{(2)}$ High levels of distress are significantly linked to medication non- adherence. ${ }^{(3)}$ Higher A1C, lower self-efficacy, and poorer dietary and exercise behaviors. ${ }^{(1,4)}$

University students are individuals in a risky place at a risky time of life. In many of the existing accounts of students with diabetes, the university is considered as a hazardous environment, a place where students can go 'out of control' and engage in hedonistic thrill-seeking behaviors. ${ }^{(5)}$ Young adults with diabetes are a forgotten group $^{(6),}$ and they don't get the resources or support needed to help them navigate the challenges of college life. ${ }^{(7)}$

\footnotetext{
* Corresponding author: E-mail: saeed.salah@kasralainy.edu.eg
} 
Screening of all patients with diabetes with the T1-DDS scales (A profile of seven major sources of DD among Type-1Diabetes Mellitus) found to be helpful in managing their DD. ${ }^{(8)}$ Based on the above mentioned views, there was a need to conduct the current study aiming to investigate the diabetes related distress among students with type (1) Diabetes Mellitus its different sources and its associated factors like glycemic control.

\section{Methods:}

This is a descriptive cross-sectional study conducted at the Students' Clinic and Students' Hospital of Assiut University. All university students who suffer from type1 diabetes and attend the students' clinic and students' hospital of Assiut University seeking medical treatment during a full academic year (2015/2016) were recruited, (total coverage sampling technique) .Students with severe disability or handicapped were excluded from study. Registers of students' clinic and students' hospital revealed that the average annual number of type 1 diabetic cases is about 84 students.

Data were collected through semi-structured interviews by using a properly designed questionnaire. Each participant had been prepared for introduction into the study by explaining the study aim followed by personal interview. Before initiation of the interview a verbal informed consent was obtained from students who agree to participate in the study.

The interviews were conducted mainly by the investigator using questionnaire composed of three sections. The first section: included sociodemographic data such as: name, age, sex, religion, college and grade, smoking. The second section: included questions about disease history, such as the onset of the disease, symptoms, diagnosis, type of insulin, diabetic relatives. The third section: included questions of Type1-Diabetes Distress Scale (T1DDS) composed of 28 items, the scale designer classified the 28 items into 7 sub-scales:

Sub-scale (1): powerlessness, included 5 items. ${ }^{(5,9,13,21,25)}$ This subscale represents the broad sense of feeling discouraged about diabetes. Sub-scale (2): Management Distress included 4 items ${ }^{(1,8,12,28)}$ representing the disappointment with one's own self- care efforts. Sub-scale (3): Hypoglycemia Distress included 4 items $(3,15,22$, and 27$)$ representing concerns about severe hypoglycemic events. Sub-scale (4): 
Negative Social Perceptions included 4 items ${ }^{(4,10,19,24)}$ representing concerns about the possible negative judgments of others. Sub-scale (5): Eating Distress included 3 items ${ }^{(2,16,23)}$ representing concerns about one's eating.

Sub-scale (6): Physician Distress included 4 items $(7,14,18,26)$ representing disappointment with current health care professional. Sub-scale (7): Friend/Family Distress included 4 items ${ }^{(6,11,17,20)}$ representing focus on diabetes amongst loved ones. Each subscale has mean-item cut-off points for distress level little or none" low", moderate and high distress. Hemoglobin A1C was estimated to each student in the study after filling the questionnaire.

\section{Ethical consideration:}

A copy of research proposal was submitted to the Ethics Review Committee of Assiut Faculty of Medicine for review and approval before conducting the study. The aim and methodology of the study were explained to the high authority in the students' hospital in Assiut University and approval was taken. The aim of the study was explained to the students. A verbal informed consent had been taken from students who agree to participate in our study.

\section{Results:}

Out of 84 eligible diabetic students, 72 agreed to participate in the study. The mean age of study participants was $(20.68 \pm 1.66)$ years; male participants represent $54.2 \%$ of study population. The majority $(83.3 \%)$ of study participants are nonsmokers. $69.4 \%$ of study participants have a positive family history of diabetes mellitus. Mean duration of diabetes is $(8.86 \pm 4.82 \%)$, the majority of study participant $(88.9 \%)$ are adherent to their treatment, although most of them $(73.5 \%)$ had inadequate glycemic control (uncontrolled diabetes).

It was found that (43.1\%) of study participant reported high distress, (30.6\%) reported moderate distress. Mean levels of reported distress varied considerably across the seven sub-scales, Powerlessness and Eating Distress have the highest mean levels (2.98 \pm 1.11 and 2.92 \pm 1.29 respectively), followed by Hypoglycemia Distress and Management Distress that have mid-range mean levels $(2.86 \pm 1.34$ and $2.75 \pm 1.19$ respectively (Figure 1, Figure 2).

Results also revealed that there is a statistical significant difference $(p=.048)$ between males and females in the physician distress. Students with positive family history of diabetes show higher eating distress $(62 \%)$ than those with negative family 
history of diabetes (27.3\%). There was also a statistically significant difference $(\mathrm{p}=.005)$ between study participants who have first degree diabetic relatives $(37.9 \%)$ and those who have second degree diabetic relatives $(71.4 \%)$ as regard their diabetes related high distress levels in the total scale and also in the hypoglycemia( $\mathrm{p}=.019)$, Negative social perception $(\mathrm{P}=.005)$ and Physician $(\mathrm{p}=.003)$ sub-scales, they all show higher distress in those who had second degree diabetic relatives $(61.9 \%, 66.7 \%$ and $52.4 \%$ respectively).

Results also show that there is no statistically significant difference between disease duration (longer and shorter) and diabetes related distress. However there is a statistically significant difference between those who were regular in their treatment and those who were irregular in their treatment as regard the high level of distress $(\mathrm{p}=.011)$. Within the physician distress sub-scale, as $75 \%$ of irregular patients showed higher level of diabetes related distress than those who were regular (29.7\%). Students with uncontrolled diabetes $(\mathrm{HbA} 1 \mathrm{C}>8)$ shows much higher levels of distress than those controlled (52\% versus $11.1 \%$ respectively) within the total scale ( $\mathrm{p}=.000)$ and also the same in the seven sub-scales (Figure 3). There is a statistically significant direct, strong correlation between the total score of diabetes related distress and the value of $\operatorname{HbA1C}(\mathrm{r}=.631, \mathrm{p}=.000)$.

\section{Discussion:}

Living with Type 1 diabetes in younger adulthood is challenging, because the many developmental and psychosocial demands of daily life compete with diabetes-related self-management tasks and thereby increase the risk of diabetes related psychosocial distress combined with poor glycemic control. ${ }^{(9,10)}$ It is known that glycemic control may deteriorate and complications may occur as early as adolescence. Further deterioration is often observed in young adulthood, when patients frequently fail to attend appointments after transitioning to adult clinics. ${ }^{(11)}$ The serious problem will arise by the fact that poor control in younger adulthood often persists throughout adulthood ${ }^{(12)}$.

After investigating the diabetic students for DD, the results revealed that (43.1\%) of them reported high distress, $(30.6 \%)$ reported moderate distress, Fisher et al., (2015) found that (7.9\%) of the sample reported high distress, $(33.7 \%)$ reported moderate distress the much higher prevalence of diabetes related distress in the present study reflected the pervasiveness of DD in these population and, confirmed 
the need to address diabetes related distress in clinical care. ${ }^{(8)}$ The differences in the levels of distress in the two studies may refer to cultural and economic differences between different societies and also the level and quality of medical services in both developing and developed countries.

The mean levels of reported distress varied considerably across the seven subscales, suggesting that the sample experienced higher mean levels of diabetes distress in some areas and lower levels in others. For example feelings of Powerlessness and Eating Distress both had the highest mean levels $(2.98 \pm 1.11$ and $2.92 \pm 1.29$ respectively), followed by Hypoglycemia Distress and Management Distress that had mid-range mean levels (2.86 \pm 1.34 and $2.75 \pm 1.19$ respectively), then Negative Social Perceptions, Family/Friend Distress and Physician Distress showed the lowest mean levels $(2.59 \pm 1.28$ and $2.56 \pm 1.28$ and $2.38 \pm 1.31$ respectively). These result were comparable with results of a study ${ }^{(8)}$ and showed that, Powerlessness and Eating Distress had the highest mean levels; Management Distress, Hypoglycemia Distress and Negative Social Perceptions had mid-range mean levels; and Physician Distress and Friends/Family Distress had the lowest mean levels.

The variety of sources of DD we identified suggests that in clinical settings it may be best to administer the entire 28-item scale, rather than only selected subscales. A high total DD score may indicate overall severity, but the variability of the individual patient DD profile suggests that different individuals experience distress from different sources that can direct clinical conversations and targeted interventions. ${ }^{(8)}$

There was a significant difference between study participants who had diabetic relatives and those with no family history of diabetes in their diabetes related distress in the Eating distress subscale, surprisingly, those with positive family history of diabetes show higher Eating distress (62\%) than those with negative family history of diabetes(27.3\%) . A review among adults with T1D found greater diabetes related distress was associated with unhealthy dietary and eating behaviors, ${ }^{(13)}$ and this phase of life is considered as a period of independence, university students are individuals in a risky place at a risky time of life. In many of the existing accounts of students with diabetes, the university is considered as a hazardous environment, a place where students can go 'out of control' and engage in hedonistic thrill-seeking behaviors. ${ }^{(5)}$ 
Higher eating distress in those with positive family history of diabetes may be explained by the family conflict about diabetes and its association with sub-optimal glycemic control and psychological distress, family members who are too involved in diabetes management can create conflict and undermine an individual's success at performing diabetes self-care activities. ${ }^{(14)}$ History of parents who perceived their child as less competent with diabetes self-management may be overly involved, inducing conflict or inhibiting their child's confidence to self-manage independently in their future life. ${ }^{(15)}$ They also may feel that diet controls their life ,as diabetic parent or diabetic family members had an experience with diabetes they will: praise them for following their diet, eat at the same time that they do, nag them about not following their diet, and eat foods that are not part of their diabetes diet, ${ }^{(16)}$ and they may feel that their families act like "diabetes police"(8).

And a statistically significant difference $(\mathrm{p}=.005)$ between study participants who had first degree diabetic relatives(37.9\%) and those who had second degree diabetic relatives(71.4\%) as regard their diabetes related high distress levels in the total scale and also in the Hypoglycemia( $\mathrm{p}=.019$, This result is in agreement with the systematic review and found that emotional support and encouragement from parents appears to be associated with lower Diabetes related Distress. ${ }^{(15)}$

Higher levels in DRD in the uncontrolled students is in agreement with a systematic review ${ }^{(15)}$ that reported a small-to-moderate positive correlation between HbA1c and DD $(r=0.13-0.30, p<0.05)$, in eight of 12 studies, whereas four studies found no significant correlation. Two studies investigated $\mathrm{HbA1c}$ and specific aspects of $\mathrm{DD}$; higher HbA1c was associated with greater parental and dietary distress and adherence related distress. There are two primary explanations for why distress would have a negative effect on glycemic control. First, distress may be directly related to glycemic control through its effect on the neuroendocrine system and sympathetic nervous system leading to the release of stress hormones. Stress hormones increase glucose production in the liver, inhibit insulin secretion in the pancreas, and/or decrease the insulin response to glucose. That is, it may directly alter blood glucose levels. ${ }^{(17)}$ A second explanation for why distress would affect negatively on glycemic control is that distress may influence glycemic control indirectly by detracting from self-care behavior. It also is possible that the two pathways are linked. ${ }^{(17)}$ 


\section{References}

1. Fisher L, Glasgow RE, Strycker LA. The Relationship Between Diabetes Distress and Clinical Depression With Glycemic Control Among Patients With Type 2 Diabetes. J Manag care Pharm JMCP. 2010;33(5):1034-6.

2. Fisher L, Hessler DM, Polonsky WH, Mullan J. When is diabetes distress clinically meaningful?: establishing cut points for the Diabetes Distress Scale. Diabetes Care. 2012 Feb;35(2):259-64.

3. Aikens JE. Prospective associations between emotional distress and poor outcomes in type 2 diabetes. Diabetes Care. 2012 Dec;35(12):2472-8.

4. Fisher L, Hessler D, Glasgow RE, Arean PA, Masharani U, Naranjo D, et al. REDEEM: a pragmatic trial to reduce diabetes distress. Diabetes Care. 2013 Sep;36(9):2551-8.

5. Balfe M. Diets and discipline: The narratives of practice of university students with type 1 diabetes. Sociol Heal Illn. 2007;29(1):136-53.

6. Wolpert HA, Anderson BJ. Young adults with diabetes: need for a new treatment paradigm. Diabetes Care. 2001 Sep;24(9):1513-4.

7. Peer Support Around the World. Peer support for U.S. college students with Type 1 Diabetes. 2006;44(0):564200.

8. Fisher L, Polonsky WH, Hessler DM, Masharani U, Blumer I, Peters AL, et al. Understanding the sources of diabetes distress in adults with type 1 diabetes. $\mathbf{J}$ Diabetes Complications. Elsevier Inc.; 2015;29(4):572-7.

9. Hislop a L, Fegan PG, Schlaeppi MJ, Duck M, Yeap BB. Prevalence and associations of psychological distress in young adults with Type 1 diabetes. Diabet Med. 2008 Jan;25(1):91-6.

10. Garvey KC, Wolpert HA, Rhodes ET, Laffel LM, Kleinman K, Beste MG, et al. Health care transition in patients with type 1 diabetes: young adult experiences and relationship to glycemic control. Diabetes Care. 2012 Aug;35(8):1716-22.

11. Saunders SA, Wallymahmed M, MacFarlane IA. Glycaemic control in a type 1 diabetes clinic for younger adults. QJM. 2004;97(9):575-80.

12. DeVries JH, Snoek FJ, Heine RJ. Persistent poor glycaemic control in adult Type 1 diabetes. A closer look at the problem. Vol. 21, Diabetic Medicine. 2004. p. 1263-8. 
13. Sturt J, Dennick K, Due-Christensen M, McCarthy K. The Detection and Management of Diabetes Distress in People With Type 1 Diabetes. Curr Diab Rep. 2015;15(11).

14. Mayberry LS, Osborn CY. Family support, medication adherence, and glycemic control among adults with type 2 diabetes. Diabetes Care. 2012;35(6):1239-45.

15. Hagger V, Hendrieckx C, Sturt J, Skinner TC, Speight J. Diabetes Distress Among Adolescents with Type 1 Diabetes: a Systematic Review. Curr Diab Rep. 2016;16(1):1-14.

16. Choi SE. Diet-specific family support and glucose control among Korean immigrants with type 2 diabetes. Diabetes Educ. 2009;35(6):978-85.

17. Helgeson VS, Escobar O, Siminerio L, Becker D. Relation of Stressful Life Events to Metabolic Control Among Adolescents With Diabetes. Heal Psychol. 2010;29(2):153-9. 


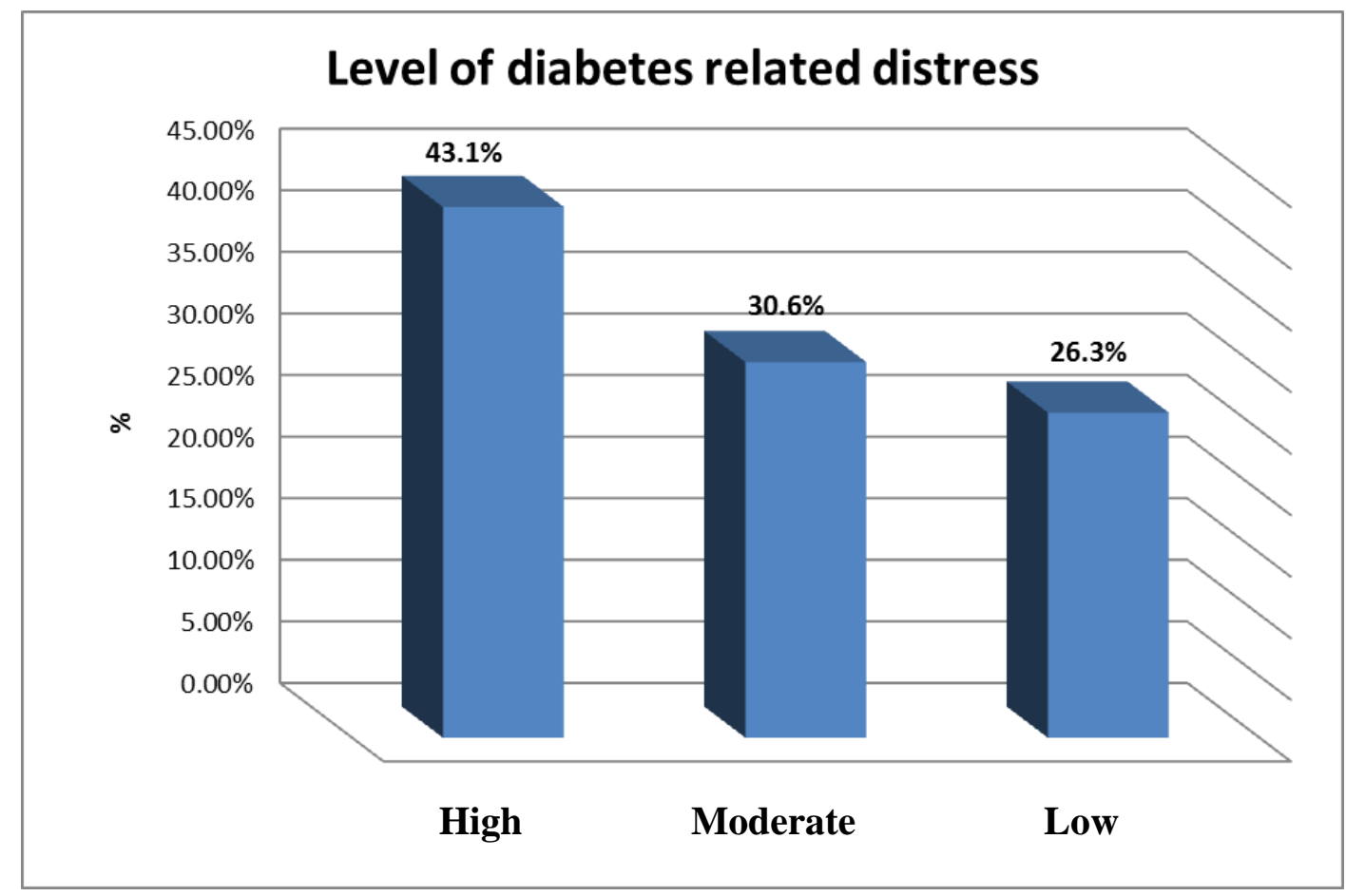

Figure(1): Distribution of study participants by the level of diabetes related distress within the total scale, Assiut University, 2016

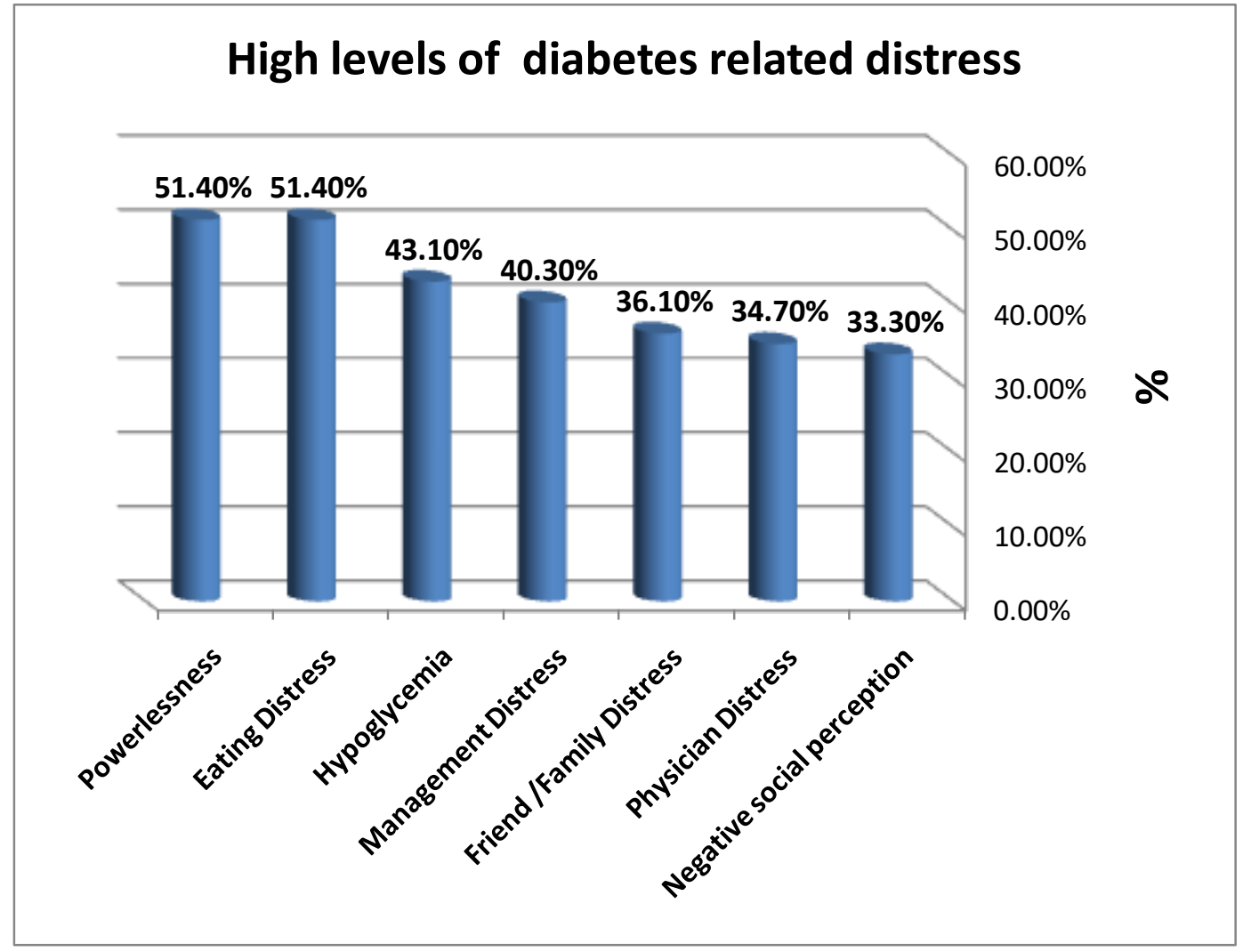

Figure (2): Proportions of high level of diabetes related distress within different sub-scales, Assiut University, 2016 


\section{High Diabetes Related Distress}

\section{$52 \%$}

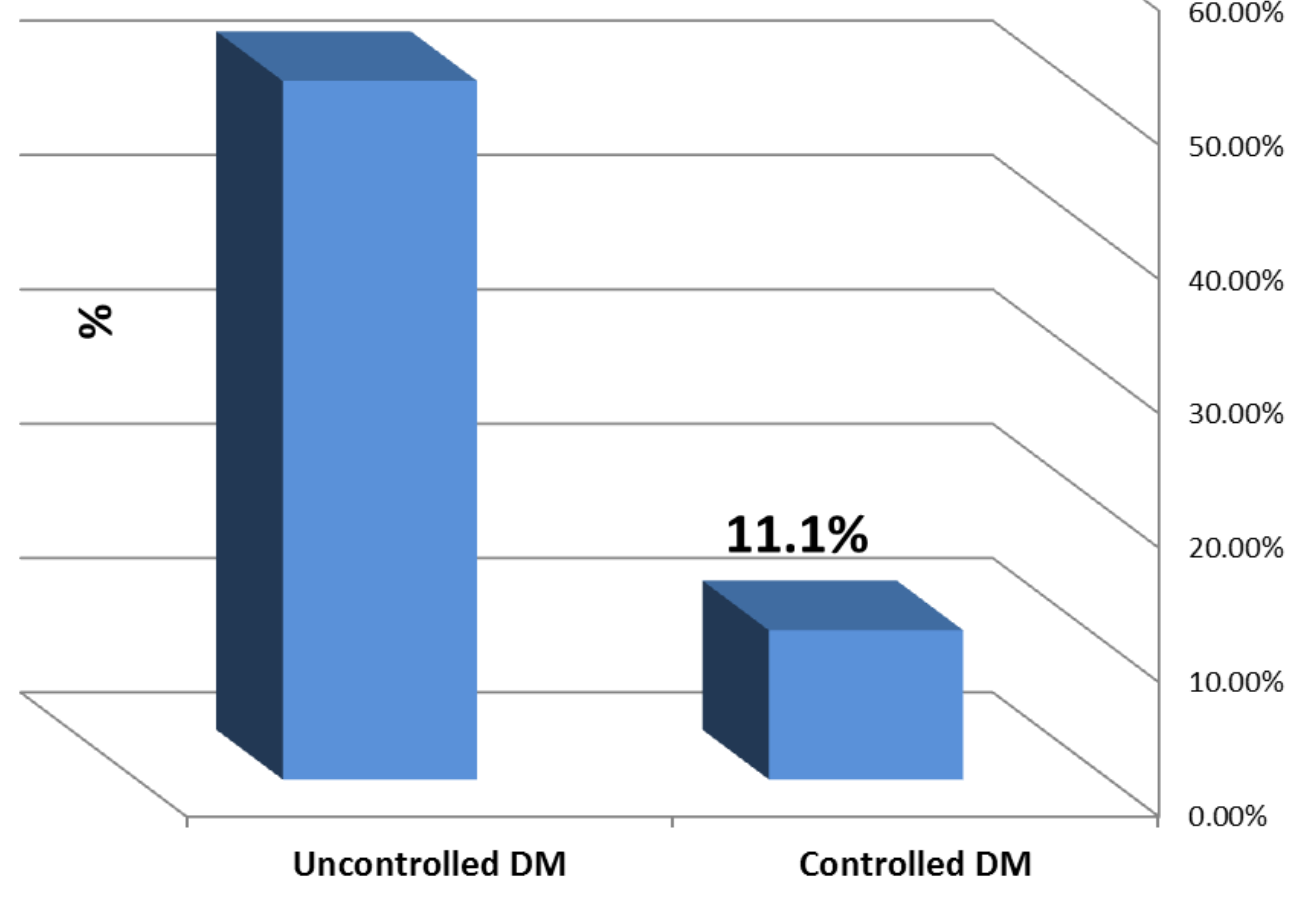

Figure (3): The relationship between the glycemic control of study participants and the high level of diabetes related distress, Assiut University, 2016

$$
\text { الملخص العربي }
$$

الضغوطات المرتبطة بداء السكري النوع الأول بين طلاب جامعة أسيوط

ترنيم محمد خضيري1 ، سعيد صلاح عبد الجليل2،محمد حسن3، ياسر محمد بدر الدين3

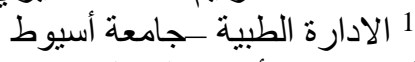

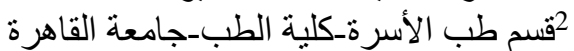

3 قسم طب المجتمع و الصحة العبة الطبة_كلية الطبـ-جامعة أسيوط

الملخص :تعتبر الضغوطات المتعلقه بداء السكري شائعة جدا بين مرضي السكري. والفحص المستمر لكل مرضي السكري لوجود مثل هذه الضغوطات يساعد في التحكم بها ـ الأهداف: هدفت الدراسة الي قياس الضغوطات المتعلقة بداء السكري النوع الاول بين المشاركين في الدراسة و التعرف علي مصادر هذه

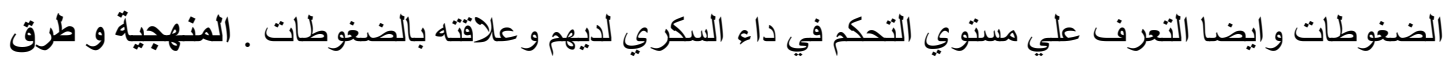

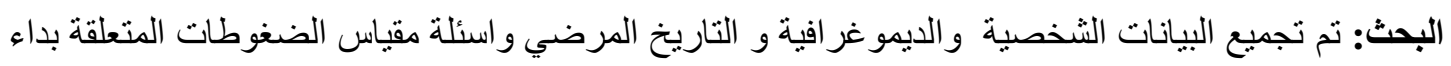
السكري كما نم عمل تحليل السكر التراكمي للمشاركين ـ النتائج: كثفت البيانات التي تم تحليلها ان متوسط عمر المشاركين في الدراسة (20.68 ـ 1.66) سنة، حوالي (69.4٪) من المشاركين في الدراسة لديهم تاريخ 
عائلي إيجابي لداء السكري، كان متوسط مدة السكري (8.86 + 4.82) سنة، وقد سجل (73.9٪) من المشاركين في الدر اسة مستويات عالية و متوسطة من الضغوطات المرتبطة بداء السكري بينما سجل كل من ضغوطات العجز (انعدام القوة) و الطعام المتوسطات الأعلي (2.98 ـ 1.11 و 2.92 ـ 1.29 على التوالي) ، تليها ضغوطات نقص السكر في الدم وضغوطات العلاج في المستوي المتوسط (2.86د 1.34 و 2.75 × 1.19 على التوالي) وقد اوضحت الدراسة بان عدم التحكم في مستوي السكر في الدم لدي المرضي كان مرتبطا بشدة بمستويات عالية من الضغوطات المرتبطة بالسكري. ونوصي هذه الدراسة بأهمية إستخدام مقدمي الرعاية الصحية لأداة سهلة للفحص الأولي (5 أسئلة ) للكثف عن الضغوطات المرتبطة بداء السكري و البدء في محادثة مع المريض حول المصادر المختلفة للضغوطات في حال تم تشخيص وجود الضغوطات المرتبطة بداء السكري للتعرف علي المصادر المختلفة للضغوطات و التعامل معها ـ الخلاصة: توصي الدراسة ايضا بأهمية توفير فرص للثباب البالغين لحضور بر امج تعليمية للعناية بداء السكري بشكل منتظم لتحسين سلوكيات

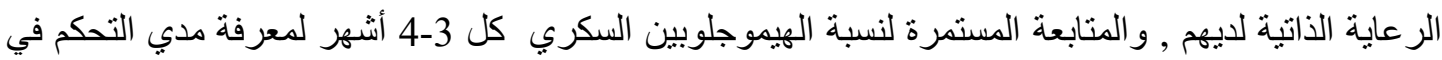
داء السكري, و أيضا من المهم تدريب مقدمي الرعاية الصحية للتعامل مع مثل هذه الحالات التي تعاني من الضغوطات المرتبطة بداء السكري. 